\title{
Concentration of Selected Elements in the Infrapatellar Fat Pad of Patients with a History of Total Knee Arthroplasty
}

\author{
Żaneta Ciosek ${ }^{1,2, *}$, Danuta Kosik-Bogacka ${ }^{3}$, Natalia Łanocha-Arendarczyk ${ }^{1}$, Karolina Kot $^{1}{ }^{1}$, \\ Maciej Karaczun ${ }^{4}$, Paweł Ziętek ${ }^{4}$, Patrycja Kupnicka ${ }^{5}\left(\mathbb{D}\right.$, Aleksandra Szylińska ${ }^{2} \mathbb{D}$ and \\ Iwona Rotter ${ }^{2}$ (D) \\ 1 Departament of Biology and Medical Parasitology, Pomeranian Medical University in Szczecin, \\ Powstańców Wielkopolskich 72, 70-111 Szczecin, Poland; nlanocha@pum.edu.pl (N.Ł.-A.); \\ kotkarolina17@gmail.com (K.K.) \\ 2 Department of Medical Rehabilitation and Clinical Physiotherapy, Pomeranian Medical University in \\ Szczecin, Żołnierska 54, 71-210 Szczecin, Poland; aleksandra.szylinska@gmail.com (A.S.); iwrot@wp.pl (I.R.) \\ 3 Independent of Pharmaceutical Botany, Department of Biology and Medical Parasitology, \\ Pomeranian Medical University in Szczecin, Powstańców Wielkopolskich 72, 70-111 Szczecin, Poland; \\ kodan@pum.edu.pl \\ 4 Chair and Clinic of Orthopaedics, Traumatology and Oncology, Pomeranian Medical University, \\ Unii Lubelskiej 1,71-252 Szczecin, Poland; karaczun@orthomail.com (M.K.); paulz@wp.pl (P.Z.) \\ 5 Department of Biochemistry and Medical Chemistry, Pomeranian Medical University, Powstańców \\ Wielkopolskich 72, 70-111 Szczecin, Poland; pkupnicka@gmail.com \\ * Correspondence: zaneta.ciosek@pum.edu.pl or ciosekzaneta@gmail.com
}

Received: 2 March 2019; Accepted: 14 May 2019; Published: 16 May 2019

\begin{abstract}
In the period of long development, the human body adapted to specific concentrations of trace elements. Any changes in the trace element content manifesting in a deficiency or excess of metals in the human body may impair the functioning of the skeletal and articular system and of the organs, and may also predispose the body to the development of diseases, i.e., osteoporosis. Our study aimed to analyze the concentrations of calcium (Ca), magnesium (Mg), fluorides (F-), and lead $(\mathrm{Pb})$ in the infrapatellar fat pad (Hoffa's fat pad) of subjects who had undergone a total knee replacement (TKR) surgery. We also endeavored to establish how concentration levels of those elements are affected by selected biological and environmental factors. The studied group comprised 48 residents of Western Pomerania Province: 34 women $(n=34)$ aged 56-87 and 12 men $(n=12)$ aged 59-85. Concentration levels of $\mathrm{Ca}, \mathrm{Mg}$, and $\mathrm{Pb}$ were established using inductively coupled plasma-atomic emission spectrometry (ICP-AES). A Thermo Orion ion-selective electrode was applied for measuring F- concentration. Subjects aged 75-87 showed higher Mg concentration values than those aged 56-74. Big city residents and smokers were found to have higher infrapatellar fat pad $\mathrm{Mg}$ concentration than their non-smoking counterparts and small town dwellers. Of all the elements whose concentrations we analyzed in our studies, only magnesium was found to correlate with smoking, place of residence, and age. Our findings regarding the quantities of selected elements in the infrapatellar fat pad may be used for the interpretation and analysis of biological, morphological, and mechanical changes in the human body.
\end{abstract}

Keywords: infrapatellar fat pad; total knee replacement; biological factors; environmental factors

\section{Introduction}

The infrapatellar fat pad or the Hoffa's fat pad (Lat. Corpus adiposum infrapatellare, HFB) is a component of the knee joint. It is located between the fibrous membrane of the joint capsule formed 
by the quadriceps muscle tendon and the synovial membrane. Its physiological function remains unknown. Some researchers believe it may serve a protective function, be involved in biomechanics of the joint, or act as storage for reparative cells after injury [1]. The infrapatellar fat pad is the site of production of growth factors, adipocytokines, as well as proinflammatory cytokines and complement components, all of which may affect the metabolism of the synovium and cartilage [2-5].

Calcium (Ca), a microelement essential for the proper functioning of the body, regulates a range of intracellular and extracellular processes. Together with magnesium $(\mathrm{Mg})$, it guarantees adequate mineralization and growth of the bone tissue. The average adult human body contains approximately $1200 \mathrm{~g}$ of calcium, which corresponds to $2 \%$ of the total body mass. Magnesium stimulates the activity of osteoblasts and phosphatase enzymes, which play an active role in osteogenesis [6]. The human body of a $70 \mathrm{~kg}$ person contains between 20 and $35 \mathrm{~g}$ of magnesium [7]. The element is present in bones, muscles, soft tissue, and intercellular fluids, making up $60 \%, 30 \%, 9 \%$, and $1 \%$ of their chemical composition, respectively [8].

The fluoride ion (F-) plays a significant biological role in the human body, participating in the binding of magnesium, calcium, phosphorus, and in the mineralization of hard tissue. The concentration of $\mathrm{F}$ - in soft tissues does not exceed $1 \mathrm{mg}$ per $1 \mathrm{~kg}^{-1}$ of body mass $\mathrm{dm}$, which is comparable to the concentration of fluorides in the plasma [9]. Lead $(\mathrm{Pb})$, a toxic heavy metal, is involved in the metabolism of vitamin D by lowering the concentration of its active form. The metal has also been recognized as one of the factors contributing to the development of osteoporosis, particularly in women during perimenopause $[10,11]$. The lead that enters the human body comes through inhalation, ingestion, or is absorbed through the skin. The rate of lead absorption depends on the form it occurs in, route of absorption, time of exposure, age, and sex [12].

Little research has been dedicated to the analysis of the mineral composition of the infrapatellar fat pad, in particular, the correlation between the concentrations of particular elements in periarticular structures in patients afflicted with osteoarthritis of the knee [13]. Therefore, it was a reasonable decision to investigate the Hoffa's fat pads levels of $\mathrm{Ca}, \mathrm{Mg}$, $\mathrm{F}-$, and $\mathrm{Pb}$ in patients who had undergone total knee replacement (TKR) and had a history of gonarthrosis. The study incorporated an analysis of the influence of selected environmental factors, such as the place of residence, smoking, and nutritional status, expressed in terms of BMI (Body Mass Index) on the concentration of some elements in the infrapatellar fat pad.

\section{Materials and Methods}

Ethical approval for this study was obtained from the Bioethics Commission of the Pomeranian Medical University in Szczecin (resolution no. KB-0012/56/14). Prior to conducting research, each of the patients obtained a full explanation of the characteristics and purpose of the study and provided written consent to participate in the study. A cohort of 46 patients, residents of the Western Pomerania region, Poland, aged 56-87 (mean age $73.4 \pm 8.5$ years), were included in the study. 34 were females aged 56-87 (mean age $73.4 \pm 8.5$ years) and the remaining 12 were males aged 56-85 (mean age $73.1 \pm 8.4$ years). The patients were hospitalized in the Department and Clinic of Orthopedics, Traumatology and Oncology of the Motor System at the Pomeranian Medical University in Szczecin. All patients underwent knee joint replacement with reconstruction of the intercondylar area, using an autologous bone graft. The main indication for the procedure was degeneration of either the left or the right knee joint ( 26 and 20 patients respectively), resulting from an underlying disease, i.e., psoriatic arthritis $(n=1)$ or knee joint injury $(n=1)$.

Prior to surgery, relevant information was obtained from each patient regarding their health status, environmental exposure (i.e., place of residence), and smoking status. Subsequently, based on their $\mathrm{BMI}$ scores, the patients were divided into two groups: One with BMI scores $<30$ and one with scores $\geq 30 \mathrm{~kg} / \mathrm{m}^{2}$.

The patients were also divided into two age groups: 56-74 years old (HS1) and 75-87 years old (HS2). Pre-operative procedures that the subjects underwent included diagnostic investigations, 
such as an X-ray and/or MRI scan of the knee joint. None of the patients suffered any post-operative complications. A sample of the infrapatellar fat pad tissue was collected from each patient during the procedure $(n=46)$. In all cases, the samples were classified as medical waste and disposed of. The material was harvested in sterile conditions. The collected samples were labeled with code numbers and stored in sterile containers at $-27^{\circ} \mathrm{C}$.

The material was weighed with a high accuracy analytical balance Sartorius ENTRIS124-1S Analytical Balance $120 \mathrm{~g} \times 0.1 \mathrm{mg}$ (Sartorius AG, Goettingen, Germany) to an accuracy of $0.0001 \mathrm{~g}$, and then dried to constant weight at $105^{\circ} \mathrm{C}$. The dried material was subsequently crushed in an agate mortar and subjected to microwave mineralization using the MARS 5 CEM system.

$\mathrm{Ca}, \mathrm{Mg}$, and $\mathrm{Pb}$ concentrations were determined using atomic emission spectrometry with excitation in inductively coupled plasma (ICP-AES, ICAP 7400 Duo, Thermo Scientific, Waltham, MA, USA), while a Thermo Orion I (Thermo Scientific) ion-selective electrode was applied for measuring the concentration of F-.

Statistical analysis was performed using Statistica 10.0 software (StatSoft, Inc. Tulsa, OK, USA). The analyses included determination of mean concentration levels of selected elements (Ca, Mg, F-, and $\mathrm{Pb}$ ) in the infrapatellar fat pad tissue. Distribution of $\mathrm{Ca}, \mathrm{Mg}, \mathrm{F}-$, and $\mathrm{Pb}$ concentrations was tested for normality by the Shapiro-Wilk test. Arithmetic mean (AM), standard deviation (SD), median (med.), and range (min-max) were used for presentation of the findings. The correlation between concentration levels of selected elements in the infrapatellar fat pad and factors like age, sex, place of residence, BMI scores, and smoking was established using the Mann-Whitney U test. Spearman's rank correlation coefficient was applied for analysis of the relationship between particular elements. The level of significance was set at $p \leq 0.05$.

\section{Results}

\subsection{Characteristics of the Entire Cohort}

Mean concentrations of $\mathrm{Ca}, \mathrm{Mg}, \mathrm{F}-$, and $\mathrm{Pb}$ in the infrapatellar fat pad of the studied patients were $1290.38,46.57,89.17$, and $0.51 \mathrm{mg} \cdot \mathrm{kg}^{-1}$ dry mass respectively (Table 1 ).

Table 1. Characteristics of the entire cohort.

\begin{tabular}{cccccc}
\hline Elements & AM & SD & Min & Max & Me \\
\hline $\mathrm{Ca}$ & 1290.38 & 1720.01 & 129.90 & 8297.79 & 565.05 \\
$\mathrm{Mg}$ & 46.57 & 35.69 & 12.81 & 188.43 & 33.25 \\
$\mathrm{~F}-$ & 89.17 & 49.28 & 20.49 & 186.95 & 83.34 \\
$\mathrm{~Pb}$ & 0.51 & 0.23 & 0.00 & 0.84 & 0.54 \\
\hline
\end{tabular}

Legend: AM-arithmetic mean, SD—standard deviation; Me-median; min-minimum, max-maximum, $\mathrm{Ca}$-calcium, $\mathrm{Mg}$-magnesium, $\mathrm{F}^{-}$-fluorine, $\mathrm{Pb}$-lead. Notes: Concentration of the elements is expressed as mg.kg-1 dry mass.

\subsection{Concentrations of $\mathrm{Ca}, \mathrm{Mg}, \mathrm{F-}$, and $\mathrm{Pb}$ in the Infrapatellar Fat Pad in Relation to Selected Biological and Environmental Factors}

The analysis of Mg levels revealed their statistically significant correlations with age $(p=0.012)$, place of residence $(p=0.047)$, and smoking $(p=0.038)$. No other statistically significant correlations were observed (Table 2). 
Table 2. Concentration levels of $\mathrm{Ca}, \mathrm{Mg}, \mathrm{F}-, \mathrm{Pb}$ in the infrapatellar fat pad and their relation to selected biological and environmental factors.

\begin{tabular}{|c|c|c|c|c|c|c|c|}
\hline & \multicolumn{7}{|c|}{ Gender } \\
\hline & \multicolumn{3}{|c|}{$M(n=12)$} & \multicolumn{3}{|c|}{$\mathrm{F}(\mathrm{n}=34)$} & \multirow{2}{*}{$p$} \\
\hline & $\mathrm{AM} \pm \mathrm{SD}$ & $\mathrm{Me}$ & Min-Max & $\mathrm{AM} \pm \mathrm{SD}$ & Me & Min-Max & \\
\hline $\mathrm{Ca}$ & $1329.90 \pm 2271.86$ & 509.73 & $180.25-8297.79$ & $1276.43 \pm 1520.86$ & 613.05 & $129.90-6705.32$ & 0.851 \\
\hline $\mathrm{Mg}$ & $60.0 \pm 55.83$ & 34.7 & $12.81-188.43$ & $41.83 \pm 24.67$ & 33.25 & $16.89-112.79$ & 0.755 \\
\hline $\mathrm{Pb}$ & $0.46 \pm 0.27$ & 0.47 & $0.001-0.828$ & $0.54 \pm 0.21$ & 0.61 & $0.09-0.84$ & 0.402 \\
\hline \multirow[t]{4}{*}{ F- } & $104.54 \pm 54.16$ & 81.05 & $52.95-186.95$ & $85.33 \pm 48.45$ & 83.34 & $20.49-182.35$ & 0.337 \\
\hline & \multicolumn{7}{|c|}{ Age } \\
\hline & \multicolumn{3}{|c|}{ HS1 $(n=26)$} & \multicolumn{3}{|c|}{ HS2 $(n=20)$} & \multirow{2}{*}{$p$} \\
\hline & $\mathrm{AM} \pm \mathrm{SD}$ & Me & Min-Max & $A M \pm S D$ & Me & Min-Max & \\
\hline $\mathrm{Ca}$ & $1201.77 \pm 1501.48$ & 592.21 & $171-6705.32$ & $1405.56 \pm 2003.94$ & 559.18 & $129.90-8297.79$ & 0.991 \\
\hline $\mathrm{Mg}$ & $37.06 \pm 27.69$ & 28.52 & $12.81-136.69$ & $58.94 \pm 41.49$ & 50.49 & $17.39-188.43$ & 0.012 \\
\hline $\mathrm{Pb}$ & $0.54 \pm 0,21$ & 0.57 & $0.04-0.84$ & $0.48 \pm 0.25$ & 0.51 & $0.001-0.83$ & 0.445 \\
\hline \multirow[t]{4}{*}{ F- } & $100.27 \pm 48.44$ & 105.56 & $24.12-186.95$ & $72.52 \pm 47.66$ & 60.3 & $20.49-182.35$ & 0.112 \\
\hline & \multicolumn{7}{|c|}{ Place of residence } \\
\hline & \multicolumn{3}{|c|}{ Under $100,000(n=11)$} & \multicolumn{3}{|c|}{ Over $100,000(n=35)$} & \multirow{2}{*}{$p$} \\
\hline & $\mathrm{AM} \pm \mathrm{SD}$ & Me & Min-Max & $A M \pm S D$ & Me & Min-Max & \\
\hline $\mathrm{Ca}$ & $1523.87 \pm 2339.66$ & 736.15 & $186.75-8297.79$ & $1216.99 \pm 1510.76$ & 544.21 & $129.90-6705.32$ & 0.817 \\
\hline $\mathrm{Mg}$ & $70.61 \pm 53.94$ & 58.49 & $12.81-188.43$ & $39.02 \pm 24.17$ & 30.39 & $16.89-112.79$ & 0.047 \\
\hline $\mathrm{Pb}$ & $0.48 \pm 0.28$ & 0.61 & $0.001-0.83$ & $0.52 \pm 0.21$ & 0.53 & $0.09-0.84$ & 0.837 \\
\hline \multirow[t]{4}{*}{ F- } & $83.23 \pm 48.12$ & 68.01 & $37.64-175.81$ & $91.33 \pm 50.63$ & 94.67 & $20.49-186.95$ & 0.796 \\
\hline & \multicolumn{7}{|c|}{ BMI } \\
\hline & \multicolumn{3}{|c|}{$<30(n=21)$} & \multicolumn{3}{|c|}{$\geq 30(n=25)$} & \multirow{2}{*}{$p$} \\
\hline & $\mathrm{AM} \pm \mathrm{SD}$ & Me & Min-Max & $\mathrm{AM} \pm \mathrm{SD}$ & Me & Min-Max & \\
\hline $\mathrm{Ca}$ & $934.63 \pm 908.29$ & 544.21 & $129.90-3755.05$ & $1589.21 \pm 2157.73$ & 640.2 & $171.05-8297.79$ & 0.708 \\
\hline $\mathrm{Mg}$ & $43.12 \pm 29.76$ & 32.19 & $12.81-136.69$ & $49.47 \pm 40.38$ & 34.31 & $16.89-188.43$ & 0.860 \\
\hline $\mathrm{Pb}$ & $0.51 \pm 0.21$ & 0.54 & $0.04-0.82$ & $0.52 \pm 0.24$ & 0.53 & $0.001-0.84$ & 0.724 \\
\hline \multirow[t]{4}{*}{ F- } & $68.23 \pm 38.32$ & 52.95 & $20.49-130.96$ & $101.29 \pm 51.71$ & 98.24 & $24.12-186.95$ & 0.121 \\
\hline & \multicolumn{7}{|c|}{ Smoking } \\
\hline & \multicolumn{3}{|c|}{ NS $(n=39)$} & \multicolumn{3}{|c|}{$S(n=7)$} & \multirow{2}{*}{$p$} \\
\hline & $\mathrm{AM} \pm \mathrm{SD}$ & Me & Min-Max & $\mathrm{AM} \pm \mathrm{SD}$ & Me & Min-Max & \\
\hline $\mathrm{Ca}$ & $1392.69 \pm 1835.57$ & 585.89 & $129.90-8297.79$ & $720.35 \pm 634.14$ & 326.94 & 171.05-1779.05 & 0.392 \\
\hline $\mathrm{Mg}$ & $50.39 \pm 37.44$ & 40.62 & $12.81-188.43$ & $25.28 \pm 7.20$ & 23.38 & $17.63-37.98$ & 0.038 \\
\hline $\mathrm{Pb}$ & $0.51 \pm 0.24$ & 0.54 & $0.001-0.84$ & $0.52 \pm 0.19$ & 0.45 & $0.29-0.75$ & 0.807 \\
\hline F- & $83.88 \pm 49.54$ & 69.81 & $20.49-186.95$ & $123.52 \pm 34.77$ & 131.29 & $75.58-155.90$ & 0.093 \\
\hline
\end{tabular}

3.3. Analysis of the Relationship between the Concentration Levels of Selected Elements in the Infrapatellar Fat Pad and Selected Biological and Environmental Factors

A considerable increase in the concentration of magnesium was observed in subjects aged over 75 years $(r=0.378, p=0.012)$, and those residing in towns and villages with populations below 100,000 inhabitants $(r=-0.298, p=0.047)$. Compared to their non-smoking counterparts, smokers were 
found to have lower levels of the infrapatellar fat pad magnesium $(r=-0.312, p=0.038)$. No other statistically significant relationship was observed (Table 3).

Table 3. Analysis of the relationship between the concentration levels of selected elements in the infrapatellar fat pad and selected biological and environmental factors.

\begin{tabular}{|c|c|c|c|c|c|c|c|c|}
\hline & \multicolumn{2}{|c|}{$\mathrm{Ca}$} & \multicolumn{2}{|c|}{ Mg } & \multicolumn{2}{|c|}{ F } & \multicolumn{2}{|c|}{$\mathrm{Pb}$} \\
\hline & $\mathbf{r}$ & $p$ & $\mathbf{r}$ & $p$ & $\mathbf{r}$ & $p$ & $\mathbf{r}$ & $p$ \\
\hline Płeć & 0.030 & 0.844 & -0.048 & 0.749 & -0.183 & 0.333 & 0.127 & 0.401 \\
\hline Age & 0.065 & 0.668 & 0.378 & 0.010 & -0.342 & 0.065 & -0.154 & 0.306 \\
\hline Place of residence & -0.036 & 0.810 & -0.298 & 0.045 & 0.052 & 0.784 & 0.033 & 0.830 \\
\hline BMI & 0.006 & 0.969 & 0.010 & 0.946 & 0.218 & 0.247 & 0.056 & 0.711 \\
\hline Smoking & -0.130 & 0.389 & -0.312 & 0.035 & 0.317 & 0.088 & -0.039 & 0.798 \\
\hline
\end{tabular}

Legend: $\mathrm{Ca}$-calcium, $\mathrm{Mg}$-magnesium, $\mathrm{F}$-fluorine, $\mathrm{Pb}$-lead., BMI—body mass index, $\mathrm{r}$-correlation coefficient, $p$-statistical significance.

\section{Discussion}

All organisms are made of chemical elements. The quality of human life is closely related to the chemical composition of the natural environment and food. In the period of long development, the human body adapted to specific concentrations of trace elements. Any changes in the trace element content, manifesting in a deficiency or excess of metals in the human body, may impair the functioning of the skeletal and articular system and the organs, and may also predispose the body to the development of diseases, i.e., osteoporosis.

Concentration levels of chemical elements in various types of human bones are being investigated by a good number of research centers. Most of these studies focus on the chemical makeup of the human femur and ribs. Similar analyses of particular elements are carried out in full blood, blood plasma, serum, urine, or horny derivatives of the epidermis. The chemical composition of the infrapatellar fat pad in patients with osteoarthritis has scarcely been covered in existing literature [13]. The few studies on the subject found that the mean concentration levels of $\mathrm{F}$ - in the infrapatellar fat pad is $62.14 \mathrm{mg} \cdot \mathrm{kg}^{-1} \mathrm{dm}$ (dry mass) [14].

Based on the results of other studies, the mean concentration of $\mathrm{Ca}$ in the knee joint components usually varies between 3000 and $5050 \mathrm{mg} \cdot \mathrm{kg}^{-1} \mathrm{dm}[15,16]$, whereas its concentration in the infrapatellar fat pad was lower than the relevant $\mathrm{Ca}$ levels in the anterior cruciate ligament and the meniscus, where it amounts to $1290.38 \mathrm{mg} \cdot \mathrm{kg}^{-1} \mathrm{dm}$. The discrepancy between the figures may be due to structural inhomogeneity of these components.

Mean level of $\mathrm{Mg}$ in the knee joint varies from 78 to $1600 \mathrm{mg} \cdot \mathrm{kg}^{-1} \mathrm{dm}[15,16]$. Our study reports the infrapatellar fat pad concentration of the element at the level of $46.57 \mathrm{mg} \cdot \mathrm{kg}^{-1} \mathrm{dm}$, much lower than its concentration in the bone tissue, which, because of the longer time it needs to form, may reflect chronic exposure and provide a basis for indirect assessment of the extent of environmental exposure.

The analysis of F- levels in bone structures demonstrated that its highest concentration is in the vertebrae $\left(>500 \mathrm{mg} \cdot \mathrm{kg}^{-1} \mathrm{dm}\right)$, ribs $\left(100-500 \mathrm{mg} \cdot \mathrm{kg}^{-1} \mathrm{dm}\right)$, and the femur $\left(100-450 \mathrm{mg} \cdot \mathrm{kg}^{-1} \mathrm{dm}\right)$, whereas its concentration in the tibia varies between 560 and $635 \mathrm{mg} \cdot \mathrm{kg}^{-1} \mathrm{dm}$ [17]. In their study carried out on a cohort of 20 patients (residents of the Western Pomerania region in 2017), Kot et al. [14] established the mean concentration of F- in the infrapatellar fat pad at the level of $62.14 \mathrm{mg} \cdot \mathrm{kg}^{-1} \mathrm{dm}$, although, in two females, the level exceeded $1000 \mathrm{mg} \cdot \mathrm{kg}^{-1} \mathrm{dm}$. One of these patients also had high levels of F- in two other parts of the knee joint, while in the second patient, the F- levels in the other parts of the knee joint were below $550 \mathrm{mg} \cdot \mathrm{kg}^{-1} \mathrm{dm}$. The mean concentration value of $\mathrm{F}$ - in the infrapatellar fat pad in the Western Pomerania residents reported in our study is $89.17 \mathrm{mg} \cdot \mathrm{kg}^{-1} \mathrm{dm}$. Any differences between obtained values might result from the size and diversity of the studied samples. 
Mean concentration of $\mathrm{Pb}$ in the knee joint elements vary between $0.20-4 \mathrm{mg} \cdot \mathrm{kg}^{-1} \mathrm{dm}[16,17]$. Our study has shown that the mean concentration of this element in the infrapatellar fat pad is lower than in the bone tissue, and amounts to $0.51 \mathrm{mg} \cdot \mathrm{kg}^{-1} \mathrm{dm}$. Bone is the major reservoir of body lead storage. The predominant mean half-life of this toxic metal in bone tissue is 20-30 years [18]. Its accumulation in bones begins during prenatal development and continues throughout life. The rate of lead absorption is determined by the extent of exposure.

A number of studies have investigated the relationship between age and concentration levels of selected elements, in particular tissues and organs. Zaichick and Zaichick [19] found that Pb levels in the femur of subjects aged 15-35 years were higher than in those aged 36-55 years. Analyzing the concentration of $\mathrm{Ca}$ in the spongy head of the femur, Brodziak-Dopierała et al. [20] observed that its levels decreased with age from 149 to $101 \mathrm{mg} / \mathrm{g} \mathrm{dm}$. A similar pattern was observed in the cortical and spongy bone of the intertrochanteric line area of the hip joint [21].

A considerable decrease has been observed in the levels of intracellular free magnesium in healthy individuals aged over 65 years [22,23]. Zaichick and Zaichick [19] recorded higher Mg levels in femoral samples collected from 15- to 35-year-old individuals than in those harvested from older subjects aged 36-55 years (2009 and $1687 \mathrm{mg} \cdot \mathrm{kg}^{-1} \mathrm{dm}$, respectively). An inverse relationship was observed by Brodziak-Dopierała et al. [20] in patients suffering from osteoarthritis and those undergoing hip replacement surgery following hip fracture. The authors demonstrated that bone Mg levels in patients aged 59 were lower than in those over 80 years old. Our study has shown that bone Mg levels of subjects aged between 75-87 years were significantly higher than in their younger counterparts aged 56-74. Analyzing the levels of F- in the femur of women from two age groups ( $>65$ and $<65$ years old), Palczewska-Komsa et al. [24] found that the former had a considerably higher concentration of the element than the latter one ( $525 \mathrm{and} 275 \mathrm{mg} \cdot \mathrm{kg}^{-1} \mathrm{dm}$, respectively). In males, the concentration of fluorides in the femur showed an opposite pattern - those less than 65 years old showed higher F- levels than their older counterparts (552 and $268 \mathrm{mg} \cdot \mathrm{kg}^{-1} \mathrm{dm}$, respectively). Łanocha-Arendarczyk et al. [17] found that the concentration levels of F- in the spongy bone of the femur were 1.5 times higher in subjects aged over 60 years old than in those less than 65 years old. $\left(519.46\right.$ and $350.39 \mathrm{mg} \cdot \mathrm{kg}^{-1} \mathrm{dm}$, respectively) The pattern, however, was not observed in the compact part of the bone (455.7 and $412.93 \mathrm{mg} \mathrm{kg}^{-1} \mathrm{dm}$, respectively). Studies into the concentration levels of heavy metals in bones showed that $\mathrm{Pb}$ levels increase with age. Kuo et al. [25] observed that the concentration of lead in the hip joint in Taiwanese patients rose with age. Subjects aged 41-60, 61-80, and over 80 years showed an increasing trend in $\mathrm{Pb}$ concentrations: 6.13, 7.62, and $9.36 \mathrm{mg} \cdot \mathrm{kg}^{-1}$, respectively.

Analyzing hip joint bone samples harvested from a number of subjects of various age groups populating the Upper Silesian Industrial Region, Brodziak-Dopierała et al. [21] recorded statistically significant differences in the cartilage concentration of $\mathrm{Pb}$ between those aged 50-60 years and individuals aged 71-80 years. Similar differences were observed in the compact bone concentrations of $\mathrm{Pb}$ between groups aged $50-60$ years and $61-70$ years.

A nationwide study by Jarosz and Respondek [26] demonstrated that nearly $70 \%$ of Polish men and $90 \%$ of women aged over 18 years suffered from dietary Ca deficiency. Analyzing differences between the chemical composition of the head of the femur samples collected from subjects aged 60-82 (inhabitants of the Upper Silesian Region) found that the levels of Ca were significantly higher in males $\left(29099.37 \mathrm{mg} \cdot \mathrm{kg}^{-1} \mathrm{dm}\right.$ ) than in females $\left(28515.42 \mathrm{mg} \cdot \mathrm{kg}^{-1} \mathrm{dm}\right)$ [27]. In their study, Tohno et al. [28] recorded that Ca concentration measured in the anterior cruciate ligament was significantly higher in males than in females (4030 $\mathrm{mg} \cdot \mathrm{kg}^{-1} \mathrm{dm}$ and $3390 \mathrm{mg} \cdot \mathrm{kg}^{-1} \mathrm{dm}$, respectively). Ziola-Frankowska [29] did not find differences in Ca concentration between men and women in the parts of the knee joint taken from patients from the Silesia region. Investigating the chemical makeup of the femur head samples collected from individuals populating the Upper Silesian Region, Brodziak-Dopierała et al. [27] noticed a higher concentration of $\mathrm{Mg}$ in males (1818.91 $\mathrm{mg} \cdot \mathrm{kg}^{-1} \mathrm{dm}$ ) compared to the relevant values recorded in women $\left(1352.49 \mathrm{mg} \cdot \mathrm{kg}^{-1} \mathrm{dm}\right)$. 
Palczewska-Komsa et al. [30] observed statistically significant differences between the femur concentrations of F- in men and women. The latter group showed a nearly $50 \%$ higher concentration of the element. Similarly, Kot et al. [14] recorded approximately 1.5 times higher F- concentration in cartilage samples collected from females than in those collected from males $\left(661.96\right.$ and $278.58 \mathrm{mg} \cdot \mathrm{kg}^{-1}$ $\mathrm{dm})$. The concentration levels of F- in spongy bone sampled from females were twice as high as in males (514.84 and $22537 \mathrm{mg} \cdot \mathrm{kg}^{-1} \mathrm{dm}$, respectively). Concentration of F- recorded in the anterior cruciate ligament tissue was also higher in women than in men and equaled respectively 125.99 and $71.90 \mathrm{mg} \cdot \mathrm{kg}^{-1} \mathrm{dm}$. Studies by Brodziak-Dopierała et al. [31] and Yoshinaga et al. [32] showed higher femur $\mathrm{Pb}$ concentrations in men than in women. The findings were confirmed by Garcia et al. [33] and Zioła-Frankowska et al. [29].

The role of $\mathrm{Ca}$ in the regulation of metabolism and body mass in humans and laboratory animals has been reported by a number of research publications. Loos et al. [34] observed that women with low Ca intake displayed the highest body fat percentage. Kamyecheva et al. [35] found a relationship between the consumption of $\mathrm{Ca}$ and BMI values in males, although the correlation was not observed in women.

Numerous studies have demonstrated lower blood plasma Mg concentration levels in obese individuals, both children and adults [36-38]. Studies conducted between 2012 and 2013 on Canadian subjects aged 3-79 years showed a negative correlation between BMI scores and serum Mg concentration levels [39]. Skalnaya et al. [40] found that $\mathrm{Pb}$ concentration in male and female hair was higher in subjects with increased BMI, regardless of age.

Our study on the interplay of selected biological and environmental parameters and the levels of some elements has not provided conclusive evidence of the influence of such factors as sex, age, BMI, and alcohol consumption on the concentrations of calcium, fluorides, or lead in the infrapatellar fat pad. What we did find was a statistically significant correlation between the concentration of magnesium and age, place of residence, and smoking.

In Europe, there are insufficient amounts of comparative data concerning concentration of selected elements in the infrapatellar fat pad. It is therefore reasonable to carry out relevant analyses in post-TKR patients with a history of gonarthrosis. Studies investigating the relationship between concentration levels of some elements and place of residence have been mainly carried out on bone tissue. Zioła-Frankowska et al. [29] did not find any material differences between $\mathrm{Ca}$ and $\mathrm{Mg}$ concentrations in compact or spongy bone samples of the femur, collected from small town inhabitants and city dwellers. Palczewska-Komsa et al. [30] found no difference in the femur concentrations of Fbetween subjects residing in Szczecin and those living in villages or other towns with populations of $6000-70,000$ people. This study has found that $\mathrm{Mg}$ levels in the infrapatellar fat pad of big city dwellers are significantly lower than those recorded in the inhabitants of small towns and villages (70.61 and $39.02 \mathrm{mg} / \mathrm{kg} \mathrm{dm}$, respectively). The difference may result from the fact that the number of the participants living in big cities of over 100,000 inhabitants was three times bigger than the relevant number of smaller city and village dwellers.

According to WHO estimates (2017), there are approximately one billion smokers worldwide. An estimated $40 \%$ of Poles smoked cigarettes in the 1980s, compared to around $20 \%$ recorded in 2015 [39]. Nicotine has been found to adversely affect the proliferation of osteoblasts and fibroblasts, as well as the production of collagen [31,41-43].

Smoking women who have entered perimenopause show a lower level of osteocalcin [42,44]. Individuals who smoke a minimum of 20 cigarettes a day demonstrate impaired intestinal $\mathrm{Ca}$ absorption [45]. In view of the above findings, tobacco smoking was recognized as a risk factor for osteoporosis and consequential bone fractures [46,47]. Little is known, though, about the influence that smoking tobacco has on mineral balance of $\mathrm{Mg}$ [48]. Some studies report lower levels of $\mathrm{Mg}$ in the serum of smokers $[49,50]$. This study has established that the concentration of magnesium in the infrapatellar fat pad of tobacco smokers is considerably lower than in non-smoking individuals (less than 26 and $51 \mathrm{mg} \cdot \mathrm{kg}^{-1} \mathrm{dm}$, respectively). 
Of all the elements we have analyzed, only Mg concentrations showed different levels in smokers and non-smokers, subjects living in big cities of over 100,000 and those residing in smaller towns and villages, as well as between subjects aged 56-74 years old and those aged 75-87 years old. Higher Mg levels were observed in the subjects aged 75-87 years, inhabitants of smaller towns and villages, and non-smokers.

\section{Conclusions}

The data our study has provided on the concentration levels of selected elements in the infrapatellar fat pad can be used for the interpretation and analysis of biochemical, morphological, and mechanical changes taking place in the human body.

\section{Limitations}

This study has potential limitations. First of all, the sample size was relatively small, which makes it difficult to identify significant relationships from the data. Secondly, all relevant tests and investigations were carried out in one centre and the subjects involved were all residents of a limited area of Western Pomerania, Poland. Another limitation results from the fact that the findings that this research yielded concerning the chemical make-up of the infrapatellar fat pad could not be verified by reference to the results of relevant studies carried out by other authors.

Author Contributions: Conceptualization, Ż.C., D.K.-B. and N.Ł.-A.; methodology, Ż.C., N.Ł.-A., K.K., M.K. and P.Z.; formal analysis, P.K. and A.S.; investigation, M.K. and P.Z.; resources, D.K.-B., N.Ł.-A., M.K., P.Z. and P.K.; writing-original draft preparation, Ż.C., I.R. and A.S.; writing-review and editing, D.K.-B., N.Ł.-A., K.K. and I.R.; visualization, Ż.C., D.K.-B. and K.K.; supervision, D.K.-B. and I.R.; project administration, Ż.C. and D.K.-B.

Funding: This research received no external funding.

Conflicts of Interest: The authors declare no conflict of interest.

\section{References}

1. Dragoo, J.L.; Johnson, C.; McConnell, J. Evaluation and treatment of disorders of the infrapatellar fat pad. Sports Med. 2012, 42, 51-67. [CrossRef]

2. Kontny, E.; Plebanczyk, M.; Lisowska, B.; Olszewska, M.; Maldyk, P.; Maslinski, W. Comparison of rheumatoid articular adipose and synovial tissue reactivity to proinflammatory stimuli: Contribution to adipocytokine network. Ann. Rheum. Dis. 2012, 71, 262-267. [CrossRef]

3. Sudoł-Szopińska, I.; Kontny, E.; Zaniewicz-Kaniewska, E.; Prohorec-Sobieszek, M.; Saied, F.; Maśliń, W. Rola czynników zapalnych i tkanki tłuszczowej w patogenezie reumatoidalnego zapalenia stawów i choroby zwyrodnieniowej stawów. Część I: Reumatoidalna tkanka tłuszczowa. J. Ultrason. 2013, 13, 192-201.

4. Belluzzi, E.; Stocco, E.; Pozzuoli, A.; Granzotto, M.; Porzionato, A.; Vettor, R.; De Caro, R.; Rugierri, P.; Ramonda, R.; Rossato, M.; et al. Contribution of Infrapatellar Fat Pad and Synovial Membrane to Knee Osteoarthritis Pain. Biomed. Res. Int. 2019, 2019. [CrossRef]

5. Eymard, F.; Chevalier, X. Inflammation of the infrapatellar fat pad. Jt. Bone Spine 2016, 83, 389-393. [CrossRef]

6. Leidi, M.; Dellera, F.; Mariotti, M.; Maier, J.A. High magnesium inhibits humanosteoblast differentiation in vitro. Magnes. Res. 2011, 24, 1-6.

7. Bancerz, B.; Duś-Żuchowska, M.; Cichy, W.; Matusiewicz, H. Wpływ magnezu na zdrowie człowieka. Prz. Gastroenterol. 2012, 7, 359-366.

8. Saris, N.E.; Mervaala, E.; Karppanen, H.; Khawaja, J.A.; Lewenstam, A. Magnesium: An update on physiological, clinical and analytical aspects. Clin. Chim. Acta 2000, 294, 1-26. [CrossRef]

9. Inkielewicz, I.; Czarnowski, W.; Krechnia, J. Determination of fluoride in soft tissues. Fluoride 2003, 36, 16-20.

10. Bijelic, R.; Milicevic, S.; Balaban, J. Risk factors for osteoporosis in postmenopausal women. Med. Arch. 2017, 71, 25-28. [CrossRef]

11. Vahter, M.; Berglund, M.; Akesson, A.; Lidén, C. Metals and women's health. Environ. Res. 2002, 88, $145-155$. [CrossRef]

12. Seńczuk, W. Toksykologia; Wydawnictwo Lekarskie PZWL: Warszawa, Poland, 2012. 
13. Krachler, M.; Domej, W.; Irgolic, K.J. Concentrations of trace elements in osteoarthritic knee-joint effusions. Biol. Trace Elem. Res. 2000, 75, 253-263. [CrossRef]

14. Kot, K.; Ciosek, Ż; Łanocha-Arendarczyk, N.; Kosik-Bogacka, D.; Ziętek, P.; Karaczun, M.; Baranowska-Bosiacka, I.; Gutowska, I.; Kalisińska, E.; Chlubek, D. Fluoride ion concentrations in cartilage, spongy bone, anterior cruciate ligament, meniscus, and infrapatellar fat pad of patients undergoing primary knee joint arthroplasty. Fluoride 2017, 50, 175-181.

15. Kumai, T.; Hamada, G.; Takakura, Y.; Tohno, Y.; Benjamin, M. Trace elements in human tendons and ligaments. Biol. Trace Elem. Res. 2006, 114, 151-161. [CrossRef]

16. Roczniak, W.; Brodziak-Dopierała, B.; Cipora, E.; Mitko, K.; Jakóbik-Kolon, A.; Konieczny, M.; Babuśka-Roczniak, M. The Content of Structural and Trace Elements in the Knee Joint Tissues. Int. J. Environ. Res. Public Health 2017, 14, 1441. [CrossRef] [PubMed]

17. Łanocha-Arendarczyk, N.; Kosik-Bogacka, D.I.; Kalisinska, E.; Sokolowski, S.; Lebiotkowski, M.; Baranowska-Bosiacka, I.; Gutowska, I.; Chlubek, D. Bone fluoride content in patient after hip and knee joint surgery. Fluoride 2015, 48, 223-233.

18. Gilbert, M.E.; Lasley, S.M. Developmental lead $(\mathrm{Pb})$ exposure reduces the ability of the NMDA antagonist MK801 to suppress long-term potentiation (LTP) in the rat dentate gyrus, in vivo. Neurotoxicol. Teratol. 2007, 29, 385-393. [CrossRef] [PubMed]

19. Zaichick, S.; Zaichick, V. The effect of age and gender on 38 chemical element contents in human femoral neck investigated by instrumental neutron activation analysis. Biol. Trace Elem. Res. 2010, 137, 1-12. [CrossRef]

20. Brodziak-Dopierała, B.; Kwapuliński, J.; Sonczyk, K.; Wiechuta, D. Disribution of magensium, calcium, sodium and potassium in tissues of the hip joint. Magnes. Res. 2013, 26, 125-131.

21. Brodziak-Dopierała, B.; Kowol, J.; Kwapuliński, J.; Kusz, D.; Cieliński, Ł. Lead and Calcium Content in the Human Hip Joint. Biol. Trace Elem. Res. 2011, 144, 6-16. [CrossRef]

22. Barbagallo, M.; Belvedere, M.; Dominguez, L. Magnesium homeostasis and aging. Magnes. Res. 2009, 22, 235-246. [PubMed]

23. Barbagallo, M.; Gupta, R.K.; Dominguez, L.J.; Resnick, L.M. Cellular ionic alterations with age: Relation to hypertension and diabetes. J. Am. Geriatr. Soc. 2000, 48, 1111-1116. [CrossRef]

24. Palczewska-Komsa, M.; Kalisińska, E.; Stogiera, A.; Szmidt, M. Fluorki w kościach człowieka-Wybrane zagadnienia. Pomeranian J. Life Sci. 2016, 62, 53-59. [CrossRef]

25. Kuo, H.W.; Kuo, S.M.; Chou, C.H.; Lee, T.C. Determination of 14 elements in Taiwanese bones. Sci. Total Environ. 2000, 22, 45-54. [CrossRef]

26. Jarosz, M.; Respondek, W. Rola Żywienia i Aktywności Fizycznej w Profilaktyce Otyłości i Przezwlektych Chorob Niezakaźnych; Gawęcki, J., Roszkowski, W., Eds.; Żywienie Człowieka a Zdrowie Publiczne: Warszawa, Poland, 2009; pp. 90-102.

27. Brodziak-Dopierała, B.; Kwapuliński, J.; Kusz, D.; Gajda, Z.; Sobczyk, K. Interactions between concentrations of chemical elements in human femoral heads. Arch. Environ. Contam. Toxicol. 2009, 57, 203-210. [CrossRef] [PubMed]

28. Tohno, Y.; Moriwake, Y.; Takano, Y.; Minami, T.; Tohno, S.; Utsumi, M.; Yamada, M.-O.; Yamamoto, K.; Okazaki, Y.; Takakura, Y. Age-related changes of elements in human anterior crucial ligaments and ligamenta capitum femorum. Biol. Trace Elem. Res. 1999, 68, 181-192. [CrossRef] [PubMed]

29. Zioła-Frankowska, A.; Kubaszewski, Ł.; Dąbrowski, M.; Kowalski, A.; Rogala, P.; Strzyzewski, W.; Łabędź, W.; Uklejewski, R.; Novotny, K.; Kanicky, V.; et al. The content of the 14 metals in cancellous and cortical bone of the hip joint affected by osteoarth. BioMed Res. Int. 2015, 815648, 1-23. [CrossRef]

30. Palczewska-Komsa, M.; Kalisińska, E.; Kosik-Bogacka, D.; Łanocha-Arendarczyk, N.; Budis, H.; Sokołowski, S.; Baranowska-Bosiacka, I.; Gutowska, I.; Chlubek, D. Fluoride in the compact bone after femoral head arthroplasty in patients from north-western Poland. Fluoride 2015, 48, 93-104.

31. Brodziak-Dopierała, B.; Kosterska, E.; Kwapuliński, J. Metal content in horizontally and vertically cut profiles of femur heads of women and men. Ann. Acad. Med. Siles. 2006, 60, 511-515.

32. Yoshinaga, J.; Suzuki, T.; Morita, M.; Hayakawa, M. Trace elements in ribs of elderly people and elemental variation in the presence of chronic diseases. Sci. Total Environ. 1995, 162, 239-252. [CrossRef]

33. García, F.; Ortega, A.; Domingo, J.L.; Corbella, J. Accumulation of metals in autopsy tissues of subjects living in Tarragona County, Spain. J. Environ. Sci. Health 2001, 36, 1767-1786. [CrossRef] 
34. Loos, R.J.; Rankinen, T.; Leon, A.S.; Skinner, J.S.; Wilmore, J.H.; Rao, D.C.; Bouchard, C. Calcium intake is associated with adiposity in black and white men and white women of the HERITAGE Family Study. J. Nutr. 2004, 134, 1772-1778. [CrossRef] [PubMed]

35. Kamyecheva, E.; Joakimsen, R.M.; Jorde, R. Intakes of Calcium and Vitamin D Predict Body Mass Index in the Population of Northen Norway. J. Nutr. 2003, 133, 103-106.

36. Jose, B.; Jain, V.; Vikram, N.K.; Agarwala, A.; Saini, S. Serum magnesium in overweight children. Indian Pediatr. 2012, 49, 109-112. [CrossRef] [PubMed]

37. Lecube, A.; Baena-Fustegueras, J.Á.; Fort, J.M.; Pelegrí, D.; Hernández, C.; Simó, R. Diabetes is the main factor accounting for hypomagnesemia in obese subjects. PLoS ONE 2012, 7, e30599. [CrossRef] [PubMed]

38. Song, Y.; Li, T.Y.; van Dam, R.M.; Manson, J.E.; Hu, F.B. Magnesium intake and plasma concentrations of markers of systemic inflammation and endothelial dysfunction in women. Am. J. Clin. Nutr. 2007, 85, 1068-1074. [CrossRef]

39. Guerrero-Romero, F.; Flores-García, A.; Saldaña-Guerrero, S.; Simental-Mendía, L.E.; Rodríguez-Morán, M. Obesity and hypomagnesemia. Eur. J. Intern. Med. 2016, 34, 29-33. [CrossRef] [PubMed]

40. Skalnaya, M.G.; Tinkov, A.A.; Demidov, V.A.; Serebryansky, E.P.; Nikonorov, A.A.; Skalny, A.V. Hair toxic element content in adult men and women in relation to body mass index. Biol. Trace Elem. Res. 2014, 161, 13-19. [CrossRef]

41. World Health Organization (WHO). WHO Report on the Global Tobacco Epidemic, Monitoring Tobacco Use and Prevention Policies; World Health Organization: Geneva, Switzerland, 2017.

42. Bogunia, M.; Brodziak-Dopierała, B.; Kwapuliński, J.; Ahnert, B.; Kowol, J.; Nogaj, E. Występowanie ołowiu i kadmu w stawie biodrowym w aspekcie narażenia na dym tytoniowy. Prz. Lek. 2008, 65, 529-532.

43. Szulc, P.; Garnero, P.; Claustrat, B.; Marchand, F.; Duboeuf, F.; Delmas, P.D. Increased bone resorption in moderate smokers with low body weight: The Minos study. J. Clin. Endocrinol. Metab. 2002, 87, 666-674. [CrossRef]

44. Olofsson, H.; Byberg, L.; Mohsen, R.; Melhus, H.; Lithell, H.; Michaëlsson, K. Smoking and the risk of fracture in older men. J. Bone Min. Res. 2005, 20, 1208-2115. [CrossRef]

45. Krall, E.A.; Dawson-Hughes, B. Smoking increases bone loss and decreases intestinal calcium absorption. J. Bone Min. Res. 1999, 14, 215-220. [CrossRef]

46. Rapuri, P.B.; Gallagher, J.C.; Balhorn, K.E.; Ryschon, K.L. Smoking and bone metabolism in elderly women. Bone 2000, 27, 429-436. [CrossRef]

47. Galażyn-Sidorczuk, M.; Brzózka, M.M.; Moniuszko-Jakoniuk, J. Estimation of Polish cigarettes contamination with cadmium and lead, and exposure to these metals via smoking. Environ. Monit. Assess. 2008, 137, 481-493. [CrossRef] [PubMed]

48. Kuźmicka, P.; Karakiewicz, B.; Rotter, I. Wpływ palenia tytoniu na wybrane składniki mineralne: Wapń, magnez, żelazo, cynk i selen—Przegląd badań. Med. Og. Nauk. Zdr. 2012, 18, 409-415.

49. Nechifor, M.; Chelarescu, D.; Mândreci, I.; Cartas, N. Magnesium influence on nicotine pharmacodependence and smoking. Magnes. Res. 2004, 17, 176-181. [PubMed]

50. Niemela, J.E.; Cecco, S.A.; Rehak, N.N.; Elin, R.J. The effect of smoking on the serum ionized magnesium concentration is method-dependent. Arch. Pathol. Lab. Med. 1997, 121, 1087-1092. [PubMed]

(C) 2019 by the authors. Licensee MDPI, Basel, Switzerland. This article is an open access article distributed under the terms and conditions of the Creative Commons Attribution (CC BY) license (http://creativecommons.org/licenses/by/4.0/). 